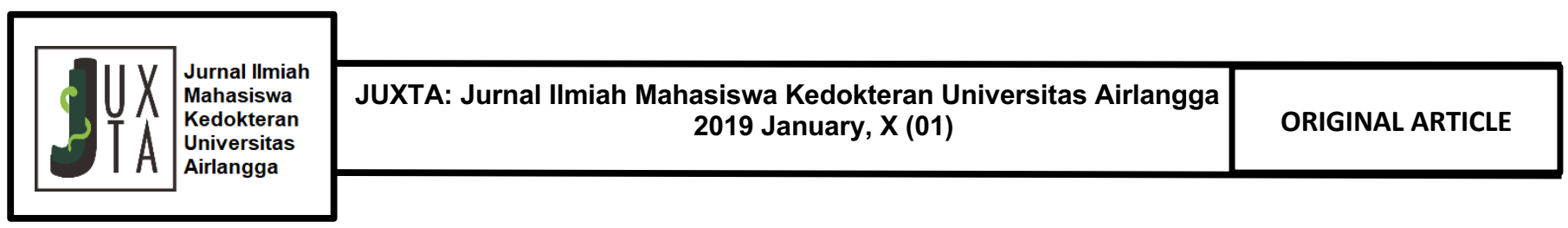

\title{
Comparison of Breast Cancer 3-years Survival Rate Based on the Pathological Stages
}

\author{
Nur Imroatul Mursyidah ${ }^{1}$ Ami Ashariati ${ }^{2^{*}}$, EttyHary Kusumastuti ${ }^{3}$, Alphania Rahniayu ${ }^{3}$
}

${ }^{1}$ Faculty of Medicine, Universitas Airlangga, Surabaya.
${ }^{2}$ Department of Internal Medicine, Faculty of Medicine, Universitas Airlangga - Dr. Soetomo General Hospital, Surabaya.
${ }^{3}$ Department of Pathology Anatomy, Faculty of Medicine, Universitas Airlangga - Dr. Soetomo General Hospital, Surabaya.

\section{A B S T R A C T}

Introduction: Breast cancer is the cancer case with the highest number of occurrences in Indonesia. The mortality rate of Breast Cancer is also high among women in Indonesia. Many factors influence the survivalibity of breast cancer. A statement from the consensus of the College of American Pathologist in 1999, there are several things that are prognostic factors for the survival of breast cancer patients, one of them are the Pathological stages at the first diagnosis. Besides, there are other factors such as clinical stages and other histopathological characteristics. The aim of this study is to determine the differences of breast cancer survival rate based on Pathological stages.

Methods: This study was conducted with a retrospective case-control design using secondary data from Dr. Soetomo General Hospital Surabaya medical records. The technique used to take the samples was purposive sampling. The sample was 45 breast cancer patients in Dr. Soetomo General Hospital In January 2015. Patient that come in January 2015 in the oncology center of Dr. Soetomo General Hospital Surabaya than followed up by Phone about their condition after three years in January 2018. The variables studied are breast cancer survival based on the pathological stages.

Results: Breast cancer patients at the stage of IIA have 100\% 3-year survival rate, stage IIB by $83.3 \%$, stage IIIA by $71.4 \%$, stage IIIB by $53.8 \%$, IIIC by $50 \%$, and stage IV by $30 \%$. With a comparison of the log-rank significance $p=0.120$.

Conclusion: The survival rate of breast cancer patients is decreasing in line with the increasing of the pathological stage of breast cancer.

\footnotetext{
*Correspondence: amiashariati@yahoo.com

JUXTA: Jurnal IImiah Mahasiswa Kedokteran Universitas Airlangga p-ISSN: 1907-3623; e-ISSN: 2684-9453

DOI: $10.20473 /$ juxta.V10I12019.38-43

Open access under Creative Commons Attribution-ShareAlike 4.0 International License (CC-BY-SA)
}

ARTICLE INFO

Article history:

Received 03 January 2019

Received in revised form 22 January 2019

Accepted 24 January 2019

\section{Keywords:}

Survival Rate,

Breast Cancer,

Pathological Stages. 


\section{Introduction}

Breast cancer has one of the highest mortality rates in the world. The World Health Organization (WHO) estimates that in 2015 there were 571,000 deaths worldwide due to breast cancer. Whereas in Indonesia, breast cancer has the highest incidence rate $(48.998 \%)$ in women, with a mortality rate of $21.4 \%$ among all types of cancer. In Western Europe, the incidence of breast cancer is very high at $89.95 \%$, but the mortality rate is only $17.5 \%$. A stark difference when compared to Southeast Asia, with the incidence rate being $31 \%$ with a mortality rate of $13.4 \%{ }^{1,2}$.

Many factors influence the survival of breast cancer patients. Including age of above 50 years and the size of the tumour cells being more than $5 \mathrm{~cm}$ without complete treatment are considered to have lower survival ${ }^{3}$. The statement from the consensus College of American Pathologist in 1999, there are three categories of prognosis factors that affect the survival of breast cancer patients, category I including TNM stage, histopathological grading, histopathology type, number of mitotic images, and hormone receptors. Category II includes c-erbB-2 (Her2-neu), biomarkers of proliferation, lymphatic and vascular invasion, and p53. Category III factors included Ploidy DNA analysis, microvessel density, and epidermal growth factor receptor, transforming growth factor-a, bcl-2, pS2, and cathepsin $D^{4}$.

Cancer stages show the extent of the spread of breast cancer. The classification according to the AJCC / American Joint Committee on Cancer Staging and End Results Reporting the stage of cancer is expressed in the TNM system (Tumour, Node, Metastasis). The TNM classification then determines the stage of breast cancer, ranging from stage I to stage IV 5 . This stage of breast cancer also affects cancer patient's life expectancy as data obtained from the American Cancer Society, 2016, that stage III cancer has a 5-year life expectancy of $72 \%$ and varies at each stage ${ }^{6}$.

Therefore, the author intends to analyze the comparison of three years of life expectancy (Survival Rate) of breast cancer patients based on the pathological stage of breast cancer in Indonesia, the selection of three years of life expectancy is selected according to the year of medical records available in Dr. Soetomo General Hospital Surabaya.

\section{Methods}

This study was conducted with a retrospective casecontrol design using secondary data from the medical record of Dr. Soetomo General Hospital Surabaya in 2015. The study was conducted by analyzing the comparison of life expectancy of breast cancer patients based on pathological stages of breast cancer. The population in this study were female breast cancer patients who visited the Oncology canterof Dr. Soetomo General Hospital Surabaya in 2015. The sample were breast cancer patients that came in January 2015 at the Oncology Center of Dr. Soetomo General Hospital Surabaya.
The subject of this study were breast cancer patients who had treatments at Dr. Soetomo General Hospital Surabaya in January 2015 that fulfilled the inclusion criteria, namely female breast cancer patients at Dr. Soetomo General Hospital Surabaya in January 2015 and patients whose telephone numbers are listed on medical records. While the samples were excluded if they met the following criteria; the patient could not be contacted again by telephone, the patient was not willing to be interviewed, and the patient whose medical record was incomplete at Oncology Center of Dr. Soetomo General Hospital Surabaya. The technique used to take the samples is purposive sampling.

This research was conducted at Dr. Soetomo General Hospital Surabaya and part of Medical Record of Oncology Center at Dr. Soetomo General Hospital Surabaya. The timing of this research is between July 2017 until October 2018.

In this study, the samples were patients who visited the Oncology Center of Dr. Soetomo General Hospital Surabaya in January 2015. Patient's telephone numbers are obtained from data in the IT section. Then the patient's condition is traced by calling the patient with the telephone number obtained. Patients who give approval for interviews by phone was then interviewed about their condition within 3 years after visiting the hospital first time and diagnosed with breast cancer and the conversation recorded. The last condition traced after three years survived with breast cancer in January 2018. Patients that are able to be contacted again then explored their medical record toget the information about the clinical and pathological characteristics of their cancer. Patients who couldn't be contacted or interviewed was excluded.

The variable in this study is survival time breast cancer patients. Survival time is time during breast cancer patients undergoing treatment at Dr. Soetomo General Hospital Surabaya for 3 years with a start point of January 2015 and an endpoint January 2018.

Pathological stages role as the another variable, suspected factor that affect the survival rate of breast cancer. Patient's staging collected and divided based on the description of Pathological stages by AJCC (American Joint Committee of Cancer) Breast Cancer Staging Manual. Divided in stages 0, I, IIA, IIB, IIIA, IIIB, IIIC and IV.

In this study, the data collected as the primary and secondary data. Primary data is the status (Life / Death) of patients after three years through the interviews and secondary data through medical records. The research instruments used were interview sheets and data collection sheets containing medical records of breast cancer patients in January 2015. The results of the study were tabulated and presented descriptively in the form of survival rates and survival diagrams. Analysis of survival was carried out using the Kaplan Meier method and the difference test was carried out using the log rank test. This calculation is done using the SPSS 16 application. 
Results

Characteristics of Breast Cancer Patient in Dr. Soetomo General Hospital Surabaya

Data taken from Medical Records in Oncology Center Dr. Soetomo General Hospital Surabaya. The study was conducted for patients who visited Oncology Center in January 2015. There were 816 visits in January 2015, 705 patients who came were breast cancer patients. The total respondents were 45 people, consisting of 27 cases that were still alive and 18 cases who had died.

Of the 705 Breast cancer visits, a telephone search was conducted for breast cancer patients. From this search, there were $58(7.1 \%)$ patients who could be followed up. Phone search aims to determine the patient's condition in after three years. The patient's condition is known from the patient herself if she is still alive, or through their families, such as a husband, child, or brother via telephone, one respondent's family is pleased to be contacted by email.
Patients who are willing to be interviewed then collected their medical record to find out the characteristics of other patients according to the variables.

Medical record data were taken in accordance with the data of patients who already followed up. The data was taken from the Oncology Center of Dr. Soetomo General Hospital Surabaya. From 58Patients who can be contacted, there are $45(77.6 \%)$ patients whom the medical recordis available to be checked.

From the interview process and retrieval of the medical record of breast cancer patients at Dr. Soetomo General Hospital Surabaya in January 2015 which can be followed up, obtained the characteristics as table1.

Table 1. General characteristics of the patient

\begin{tabular}{|c|c|c|c|}
\hline Characteristics & \multicolumn{3}{|c|}{ Number (\%) } \\
\hline \multicolumn{4}{|l|}{ Three Years Outcome $(n=45)$} \\
\hline Died & \multicolumn{3}{|c|}{$18(40 \%)$} \\
\hline Alive & 27 & \multicolumn{2}{|l|}{$(60 \%)$} \\
\hline \multicolumn{4}{|l|}{ Age $($ Years $)(n=45)$} \\
\hline $30-39$ & \multicolumn{3}{|c|}{$8 \quad(17.8 \%)$} \\
\hline $40-49$ & \multicolumn{3}{|c|}{$15(33.3 \%)$} \\
\hline $50-59$ & \multicolumn{3}{|c|}{$14(31.1 \%)$} \\
\hline $60-69$ & \multirow{2}{*}{\multicolumn{2}{|c|}{$(2.2 \%)$}} & $(15.6 \%)$ \\
\hline $70-79$ & & & \\
\hline \multicolumn{4}{|l|}{ Stages $(n=44)$} \\
\hline IIA & & 4 & $(9.1 \%)$ \\
\hline IIB & & 6 & $(13.6 \%)$ \\
\hline IIIA & & 7 & $(15.9 \%)$ \\
\hline IIIB & & 13 & $(29.5 \%)$ \\
\hline IIIC & & 4 & $(9.1 \%)$ \\
\hline IV & & 10 & $(22.7 \%)$ \\
\hline \multicolumn{4}{|l|}{ Histopathology Type $(n=45)$} \\
\hline Invasive Ductal $\mathrm{Ca}$ & & 35 & $(79.5 \%)$ \\
\hline Invasive Lobular $\mathrm{Ca}$ & & 3 & $(6.8 \%)$ \\
\hline Invasive Ca Papillary & & 2 & $(4.4 \%)$ \\
\hline Mixed Type & & 4 & $(9.1 \%)$ \\
\hline \multicolumn{4}{|l|}{ Grading $(n=39)$} \\
\hline Well Differentiated & & 5 & $(12.8 \%)$ \\
\hline Moderate Differentiated & & 14 & $(35.9 \%)$ \\
\hline Poor Differentiated & & 20 & $(51.3 \%)$ \\
\hline \multicolumn{4}{|l|}{ Metastasis State $(n=44)$} \\
\hline No Metastasis & & 20 & $(45.5 \%)$ \\
\hline Metastasis* & 24 & $(54.5 \%)$ & \\
\hline Lungs & & 11 & $(25.0 \%)$ \\
\hline Pleura & & 2 & $(4.5 \%)$ \\
\hline Liver & & 5 & $(11.4 \%)$ \\
\hline Contralateral lymph node & & 3 & $(6.8 \%)$ \\
\hline Bone & & 3 & $(6.8 \%)$ \\
\hline Brain & & 1 & $(2.3 \%)$ \\
\hline
\end{tabular}


* There are more than one metastatic organ in one patient

The total number of patients who can be followed up and agreed to do an interview about their condition until January 2018 was as many as 45 patients. Of these, patients who survived were $60 \%$ or as many as 27 people. In terms of age, patients aged between 40-49 years were the most common with 15 people $(33.3 \%)$ and patients between 70-79 years being the least, with only 1 person $(2.2 \%)$. The oldest age was 70 years and the youngest 34 years. The average breast cancer patient is 49.64 years old with a median of 49 years.

Patients whose primary tumor stage data are listed in the medical record are 44 people. Patients with advanced stage IIIB at diagnosis is the most numerous with as many as 13 people $(29.5 \%)$ and patients who came with the initial tumor stage of IIA and advanced stage III C amounted to the same number with only 4 people $(9.1 \%)$. When taking into account the type of a tumor through an Anatomical Pathology examination, out of 44 total patients, there were 35 patients with histopathological type Invasive ductal carcinoma $(77.8 \%)$, with the least common type was Invasive Carcinoma Papillary with only 2 patients $(4.4 \%)$. For Grading, there were 6 people excluded because of incomplete data in their medical records, which the number of patients with Poor Differentiation was found in more than half the number of samples, which was $51.3 \%$.

Similar with most patients diagnosed at an advanced stage, patients whose tumor had metastasized to other organs also reached almost half the sample amounting to $45.5 \%$. The three organs that were the target of the most metastases were as many as 11 patients $(25 \%)$ metastasized to the lungs, 5 patients $(11.4 \%)$ metastasized to the liver and 3 patients $(6.8 \%)$ metastasized to the contralateral lymph node.

\section{Overall Survival 3-years Survival Rate of Breast Cancer Patient in Dr. Soetomo General Hospital Surabaya}

Among 45 cases of breast cancer studied there were as many 27 cases censored (alive) and 18 experienced cases (died). So that, the overall probability of 3-year survival of breast cancer patients according to KaplanMeier's calculation at $0.6(60 \%)$. That matter tabulated in table 2 and shown in figure 1.

Table 1. Three Years Survival Time for Breast Cancer Patients in Dr. Soetomo General Hospital Surabaya Surabaya

\begin{tabular}{ccc}
\hline Alive n (\%) & Died n (\%) & Total \\
\hline $27(60 \%)$ & $18(40 \%)$ & $45(100 \%)$ \\
\hline
\end{tabular}

Survival Function

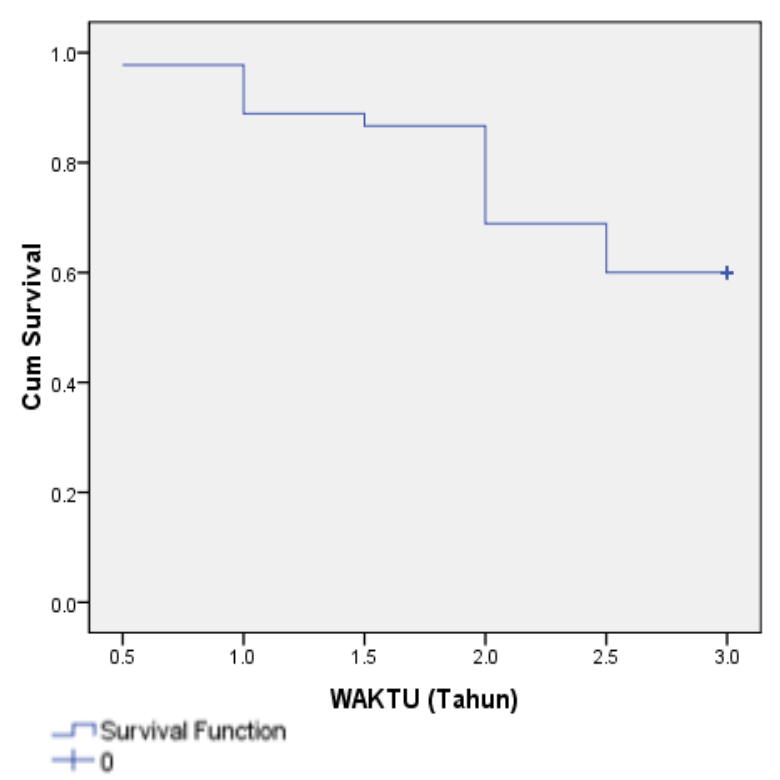

Diagram 1. Three Years Survival Time for Breast Cancer Patients in Dr. Soetomo General Hospital Surabaya Surabaya

\section{Survival rate based on the pathological stage of breast cancer}

In this calculation, patients are grouped into stage categories namely IIA, IIB, IIIA, IIIB, IIIC, and IV. Patients with breast cancer which has the highest survival rate are patients with pathological IIA stage that is $100 \%$ of patients still alive after 3 years. Whereas patients with the worst survival rate were patients with stage IV, which was only $30 \%$. With the number of patients who died as many as 7 people out of 10 people was detected at the pathological stage IV. Tabulation of the results of survival calculations is illustrated in table 3.

Table2. The Relation of Pathological Stages BreastCancer

Patients with 3 YearsSurvival Rate in Dr. Soetomo General Hospital Surabaya Surabaya

\begin{tabular}{cccccc}
\hline \multicolumn{2}{c}{ Characteristic } & $\begin{array}{c}\text { Alive } \\
\mathbf{n}(\%)\end{array}$ & $\begin{array}{c}\text { Died } \\
\mathbf{n}(\%)\end{array}$ & $\begin{array}{c}\text { Overall } \\
\text { Survival }\end{array}$ & $\mathbf{p}$ \\
\hline Stadium & IIA & $4(100,0 \%)$ & $0(0 \%)$ & & \\
& IIB & $5(83,3 \%)$ & $1(16,7 \%)$ & & \\
& IIIA & $5(71,4 \%)$ & $2(28,6 \%)$ & $26(59,1 \%)$ & 0,120 \\
IIIB & $7(53,8 \%)$ & $6(46,2 \%)$ & & \\
IIIC & $2(50,0 \%)$ & $2(50,0 \%)$ & & \\
IV & $3(30,0 \%)$ & $7(70 \%)$ & & \\
\hline
\end{tabular}

Dr. Soetomo General Hospital Surabaya Surabaya

Further statistical analysis with the log rank test showed no difference between the pathological stage and the 3-year survival rate of breast cancer patients $\lambda=0.05$ 
(chi-square $=8.743, \mathrm{df}=1, \mathrm{p}=0.120$ ). The difference is illustrated in Figure 2.

\section{Survival Functions}

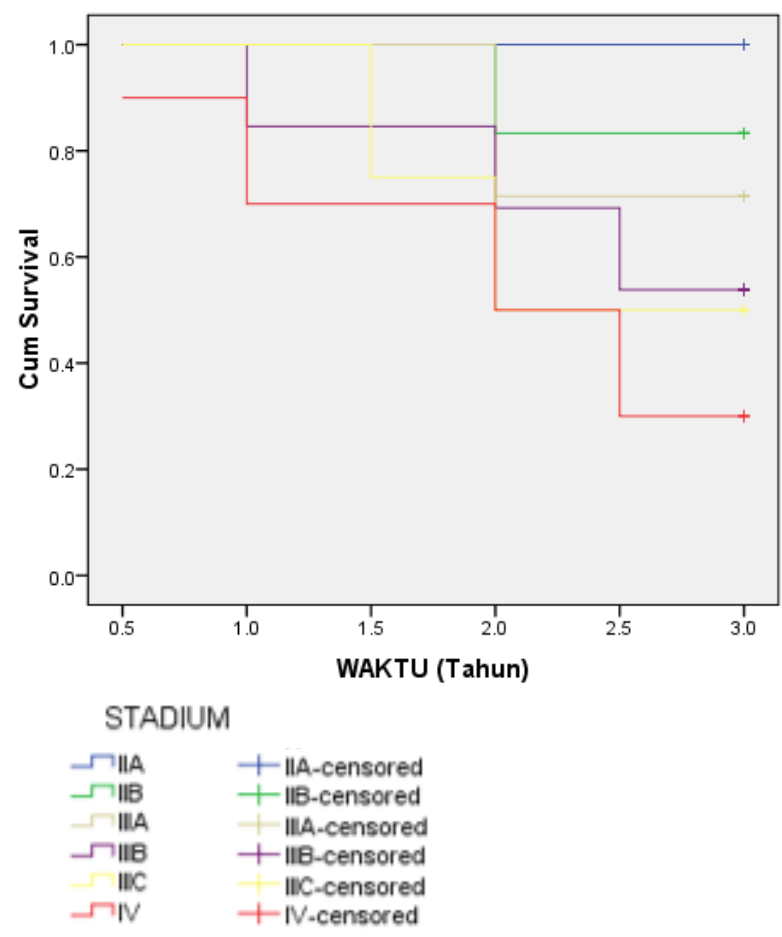

Diagram 2. The Relation of Pathological Stages Breast Cancer Patients with 3 Years Survival Rate in Dr. Soetomo General Hospital Surabaya

\section{Discussion}

\section{Characteristics of Research Subjects}

Breast cancer patients at Dr. Soetomo General Hospital Surabaya are dominated by women aged between $40-49$ years. While the least common age at the time of diagnosis is more than 70 years of age. This is similar to a study of 220 women in America where their average age of developing breast cancer was when they were 43.5 years old ${ }^{7}$. This result is also similar to the results of the SEER (Surveillance, Epidemiology, and End Results) conducted by the $\mathrm{NCl}$ (National Cancer Institute), that the incidence of breast cancer is in line with reproductive age, which increases at a lower rate. Estrogen hormones in the body are still high ${ }^{8}$.

At present, breast cancer has developed into the most common cancer in women in the world ${ }^{9}$. Besides clinical examination, examination of anatomic pathology is also important because it has become the golden standard for diagnosing malignancy in a breast tumor. In this study, most of the breast cancers that were examined were of the type of Infiltrating Ductal Carcinoma (IDC) or which could be called Invasive Carcinoma of NST and the remaining mixture of various typesother histology. This is similar to another study of that type of breast cancer in Dr. Soetomo General Hospital Surabaya from January to July 2015 dominated by Invasive Carcinoma of NST. In
America, IDC type is the most common type of breast cancer more than $80 \%$ number of populations ${ }^{10,11}$.

Histopathological examination aims to find out the differences in new cancer cells from their original cells. More than half the number of samples of patients studied was poorly differentiated $(51.3 \%)$ at diagnosis. Only $12.8 \%$ of patients are well differentiated. Recent research at Dr. Soetomo General Hospital Surabaya, patients with grades II and III are almost as many as around $43 \%$. This number comparison is also the same as foreign research from Southampton General Hospital ${ }^{12,13}$. The amount of bad differentiation from grading histopathological examination result is comparable to patients who come with advanced stages.

Patients with metastasis numbered 40 people. Most metastasis affects the lungs and the least in the brain. The most common organs are targets of breast cancer metastasis, namely the lungs, contralateral breast, and liver ${ }^{10}$. Because these organs are close to the breast. Metastasis in breast cancer patients at Dr. Soetomo General Hospital Surabaya is more often detected because patients carry out continuous therapy at this hospital.

\section{Overall Survival 3-years Survival Rate of Breast Cancer Patient in Dr. Soetomo General Hospital Surabaya}

From 45 breast cancer patients who were able to be followed up, there were 27 people $(60 \%)$ who were still alive and 18 people (30\%) patients who died. The total mortality is almost the same as the mortality rate in the previous study which stated that the number of patients who died after 3 years was $29.6 \%{ }^{14}$. However, studies carried out on breast cancer populations in Taiwan showed that 3 years of survival overall was $89.2 \%$. This value is higher than overall survival in this study which was only $60 \%{ }^{15}$.

The low survival rate of breast cancer patients in this study is likely due to patients at Dr. Soetomo General Hospital Surabaya tends to just check the condition of her breasts at an advanced stage (Stage IIIB 29.5\%, Stage IV $22.7 \%$ ). So, patients didn't get treatment quickly. It can also be due to awareness of the importance of early detection of breast cancer in Indonesia which is still low. From research conducted in Semarang, Indonesia, $70.1 \%$ of women did not know the importance of conducting breast self-examination to prevent breast cancer ${ }^{16}$.

Three years Survival Rate of Breast Cancer Patient in based on Pathological Stages at Dr. Soetomo General Hospital Surabaya

Most breast cancer patients come at stage IIIB $(29.5 \%)$ and stage IV $(22.7 \%)$ and at least in stage IIA and IIIC $(9.1 \%)$. Patients generally come in an advanced stage and rarely comein the early stages. This is because the $\mathrm{Dr}$. Soetomo General Hospital Surabaya is type C hospital that mostly received referral patients so that patients are rarely examined when the lump is small. From the data collection process and interviews, it is known that most breast cancer 
patients come to Dr. Soetomo General Hospital Surabaya because of post-mastectomy that referral to carry out chemotherapy and radiotherapy from the regional hospital around.

In contrast to research carried out in Geneva, Europe, the number of breast cancer patients at the initial stage is the most number than the advanced stage. This is done because the frequency of screening in young women is increasing, surveillance and early detection of familial risk factors are better. It was also stated that there was a $20 \%$ increase in the use of MRI in the screening process of young women in the country ${ }^{17}$.

From the calculation with Kaplan-Meier survival analysis Breast cancer patients at the stage of IIA have $100 \% 3$-year survival rate, stage IIB by $83.3 \%$, stage IIIA by $71.4 \%$, stage IIIB by $53.8 \%$, IIIC by $50 \%$, and stage IV by $30 \%$. Patients with initial stages tend to have better survival rate then a patient at the late stages. Survival rates are best found in stage IIA (100\%) and the worst in stage IV (30\%).

Calculation of survival rates for breast cancer patients at each stage has decreased. This is in accordance with research conducted at Barangwanath Academic Hospital, Johannesburg, Africa which mentions a 3-year life rate of breast cancer patients at stage I / II of $84 \%$ and stage III / IV of only $56 \%{ }^{18}$. But in calculating the survival rate based on the pathological stage there was no significant difference with a comparison of the log-rank significance $p$ $=0.120$. we can conclude that each stage is not the precise factors to determine the prognostic of a breast cancer patient in Dr. Soetomo General Hospital Surabaya.

\section{Conclusion}

The survival rate of breast cancer patients at $\mathrm{Dr}$. Soetomo General Hospital Surabaya will decrease in line with the increase in the pathological stage of breast cancer. Patients diagnosed with breast cancer in stage IIA have the best 3-year survival rate compared to cancer patients who are at the final stage, stage IIIB or stage IV.

\section{CONFLICT OF INTEREST}

The author stated there is no conflict of interest

\section{REFERENCES}

1. Organization WH. Breast Cancer: Prevention and Control. 2017.

2. Jemal A, Bray F, Center MM, Ferlay J, Ward E and Forman D. Global cancer statistics. CA: A Cancer Journal for Clinicians. 2011; 61: 69-90.

3. Wahyuni AS. Analisis Ketahanan Hidup 5 Tahun pada Penderita Kanker Payudara di Rumah Sakit Kanker Dharmais. 2002.

4. L Fitzgibbons P, L Page D, Weaver D, et al. Prognostic Factors in Breast Cancer. College of American Pathologists Consensus Statement 1999. 2000, p.96678.

5. Swerdlow SHea. World Health Organization Classification of Tumours. Lyon, Framce: IARC Press, 2008.
6. Elston CWE, Ian O. Pathological Prognostic Factors in Breast Cancer. I. The Value of Histological Grade in Breast Cancer: Experience from A Large Study with Long-Term Follow-Up. Histopathology. 1991; 19 5: 40310.

7. Avis N, Crawford S and Manuel J. Quality of Life Among Younger Women with Breast Cancer. 2005, p.3322-30.

8. Anggorowati L. Faktor Risiko Kanker Payudara Wanita. Jurnal Kesehatan Masyarakat. 2013; 8.

9. Ferlay J, Soerjomataram I, Dikshit R, et al. Cancer Incidence and Mortality Worldwide: Sources, Methods and Major Patterns in GLOBOCAN 2012. International Journal of Cancer. 2015; 136: E359-E86.

10. Herasmoro AP. Gambaran Kejadian Metastatis pada Pasien Kanker Payudara di Poli Onkologi Satu Atap (POSA) RSUD DR. Soetomo Surabaya Periode JanuariJuni 2015. Universitas Airlangga, 2017.

11. Borst MJ and Ingold JA. Metastatic Patterns of Invasive Lobular Versus Invasive Ductal Carcinoma of the Breast. Surgery. 1993; 114: 637-42.

12. Augustya B. Profil Ekspresi Reseptor Estrogen dan Reseptor Progesteron dengan Grading Histopatologis pada Kanker Payudara Premenopouse di RSUD DR. Soetomo Surabaya. Universitas Airlangga, 2017.

13. Silcocks P. Staging and Grading in Breast Cancer. British Journal of Cancer. 1983; 47: 733.

14. Stotter A, Reed M, Gray L, Moore N and Robinson T. Comprehensive Geriatric Assessment and Predicted 3year Survival in Treatment Planning for Frail Patients with Early Breast Cancer. British Journal of Surgery. 2015; 102: 525-33.

15. Chang H-T, Shi H-Y, Wang B-W and Yeh S-CJ. Breast Cancer Incidence and Predictors of Surgical Outcome: a Nationwide Longitudinal Study in Taiwan. Clinical Oncology. 2017; 29: 362-9.

16. Desanti OI and IM Sunarsih S. Persepsi Wanita Berisiko Kanker Payudara Tentang Pemeriksaan Payudara Sendiri Di Kota Semarang, Jawa Tengah. Berita Kedokteran Masyarakat. 2010; 26: 152.

17. Bouchardy C, Fioretta G, Verkooijen $\mathrm{H}$, et al. Recent Increase of Breast Cancer Incidence among Women Under the Age of Forty. British Journal of Cancer. 2007; 96: 1743 .

18. Cubasch H, Dickens $C$, Joffe $M$, et al. Breast Cancer Survival in Soweto, Johannesburg, South Africa: A Receptor-Defined Cohort of Women Diagnosed from 2009 to 11. Cancer Epidemiology. 2018; 52: 120-7. 